Förster, Till and Siegenthaler, Fiona (2018): "Introduction: Re-Imagining Cities in Africa", in Re-imagining the African City: The Arts and Urban Politics (eds. Fiona Siegenthaler and Till Förster). Special issue Social Dynamics 44(3), 10 pages.

DOI: $10.1080 / 02533952.2018 .1512938$

\title{
Introduction: Re-Imagining Cities in Africa
}

Till Förster ${ }^{\mathrm{a}}$ and ${ }^{\mathrm{b}}$ Fiona Siegenthaler

${ }^{a}$ Department of Anthropology, University of Basel, Basel, Switzerland; 'bepartment of Anthropology, University of Basel, Basel, Switzerland and Visual Identities in Art and Design Research Centre, University of Johannesburg, Johannesburg, South Africa

\section{The urban everyday}

Today, African cities seem to be everywhere. No longer bound to physical space, they seem to move across the land, transforming it into an endless cityscape of houses, shacks and streets. Streams, lakes and lagoons are turning into backwaters where all kinds of domestic works are conducted. There seem to be few places where life is less attractive than in the boundless urban everyday. It has become increasingly difficult to distinguish urban life-worlds from the countryside - so vast are the surfaces that urban worlds cover today. Cities like Lagos, Douala, Kinshasa, Addis Ababa, or Johannesburg do not extend into what was once called a hinterland - they rather penetrate it underneath the surface and, in a striking parallel to the state, the Etat rhizome (Bayart 1989), they pop up in unforeseen places. Perhaps, la ville rhizome, "the city with branched rhizomes," characterises the current state of urban sprawl in Africa better than models based on the Western historical experience. In any case, urban ways of living are no longer tied to the well-contoured 
space that the city once was. They creep into the hinterland along roads and highways, inspiring dreams and illusions about what the city has to offer as well as ideas and visions about one's own future - dreams that rarely become true, illusions about a future that is uncertain but still more promising than the present.

Cities in Africa have not lost an inch of their attractiveness. The capitals of most African states attract people from all over the country if not from the entire sub-region. Africa has the fastest pace of urbanisation worldwide (Freire, Lall, and Leipziger 2015; UN Habitat 2016). The growth of cities like Abidjan, Dakar or Dares-Salaam is qualified as "unsustainable" and "...making the 'emerging futures' of too many cities unpromising" (UN Habitat 2016,177). And nonetheless, most urbanites and migrants still see the city as a big promise - a promise that seems to refute all warnings and gloomy predictions. Obviously, the imagination of the city is much stronger than the harsh realities of urban life. Hence our main question: How do the images of the city in Africa emerge and what makes them so appealing?

The focus of our enquiry is how the people - ordinary citizens in ordinary cities (Robinson 2006) - and artists in particular, imagine the urban. Our aim is not to re-imagine the city solely from a theoretical perspective: ${ }^{1}$ our starting point is to take the urbanites' own creative work as a foundation to advance our understanding of what the city is for them. Inductive theorising necessitates an empirical basis and is the second step of our inquiry into the imageries and images of urban Africa. This collection of articles also does not look at the exceptional, at shiny facades or the authorised images of growth and progress. The authors of this special issue do not aim at examining the attractiveness of 'Global' or 'World-Class Cities' that planners try to design and the narratives of success that urban councils promote. The articles assembled in this issue rather look at the urban everyday and at how its inhabitants, among them artists and writers, imagine their city. They look at the usual madhouse - the seemingly chaotic life in the streets, this most public part of African cities - and every now and then, often critically, at elitist spaces. The papers 
of this collection thus offer views on and under the four or six lane highways that pass over the urban sprawl where ordinary people try to make a living, where they try to cope with the many constraints that urban life has for them and to live its hopes and promises. Perhaps because of their unattainability for many, the elitist and upmarket places of the city also do figure in the artists' urban reality and claim a place in their imaginary.

Adopting an inductive approach also means to follow the actors' imagination as a social practice. If "[u]rban life is the irreducible product of mixture" (Amin and Thrift 2002, 3), the interaction of people living their cities is the only viable way to trace the formation of city images. We thus echo recent theoretical contributions to urban studies that analyse urban practices as connectivity, flexibility, movement and contingency. ${ }^{2}$ Accordingly, we understand imagination as a social practice that produces images. To trace this social practice means to engage in it; to look at how urbanites as social actors make use of material pictures that may sediment as more stable mental images if others confirm their appropriateness. ${ }^{3}$ They may also be questioned if they do not mirror the expectations and hopes for a better future. We thus want to avoid a double misunderstanding: First, city images are no stable or static representation - neither of the city nor of its experience. ${ }^{4}$ Second, the formation of images is not simply a discursive process. Though they are inevitably linked to discourse and hence embedded in urban politics, images are not completely absorbed by discursive formations. There is a surplus, a sensory, visual quality that neither language nor the model of discourse can capture. Whether and how that quality is experienced is a central empirical question - a question that the contributions to this issue address from many angles. 
Imagery and image

It is difficult, if not impossible, to reduce a living city to only one image. Some actors, for instance mayors and urban councils, may have an interest in transforming the multifaceted imagery of the populace to only one image, preferably a representative image that serves their aims. Marketing departments of urban administrations may also try to invent and promote a particular image of the city. They might build on ideas that are shared by the populace or perhaps a part of it. More often, however, marketing experts try to re-shape the city image or re-invent a brand by highlighting what they see as the city's positive aspects. This process, which is an intrinsic part of urban politics, usually aims at solidifying a "progressive" image of the city.

Lagos may serve as an example. In 2013, the state government of Lagos produced a short film titled "Lagos: Africa's Big Apple." The film was commissioned by mayor Babatunde Fashola, whose ambitions to make Lagos Africa's Big Apple culminated in a gigantic luxury housing project: shiny skyscrapers, an artificial marina and a reproduction of Fifth Avenue in New York (Okeowo 2013). Of course, the reference to New York, the "real" Big Apple, was meant to claim a similar place in the global urban hierarchy - or at least in Africa as a continent. The implicit comparison was indeed made before in a Twitter conversation, but it had not been part of the popular discourse about the city and its character. The mayor's vision of Lagos met immediate opposition as it had "little consideration for the poor," as Alexis Okeowo (2013) wrote, quoting residents of Makoko, Lagos' infamous slum on the water. Such attempts to promote and eventually to immobilise a city image aim at representation, that is, at bringing the process of imagining to a halt that allows those who have the respective interests to make use of that authorised, "frozen" representation. More often than not, such attempts immediately instigate resistance - very much as Lagosians opposed mayor Fashola's image of Lagos as Africa's Big Apple. 
However, marketing departments do not exist everywhere. In most African countries, ${ }^{6}$ only primary cities can afford to pay publicity experts, in particular capitals and metropolises such as Cape Town or Douala. In primary cities, the conflict between artists, their image of a city and other actors can be particularly fierce. ${ }^{7}$ In other parts of Africa, the "authorised" city image is rather the exception than the rule. The politics of representation are much more complex and sometimes messy in secondary cities where urban councils have little means to address such issues. This leaves more space for popular imageries that may eventually coalesce in city images but may also become a mirror of contingent political articulations. Whether a dominant city image finally emerges depends on many factors - but it is always part and parcel of the urban "mixture", as Ash Amin and Nigel Thrift (2002) remind us. This mixture, the myriad of interactions, connections, and movements, does not only call for a sophisticated urban theory that includes all societal milieus and their visions of the city, it also requires thorough empirical research - including at the bottom of the social order.

Two problems arise. First, it would be a false conclusion to assume that the formation of city images is, with a pinch of salt, an extension of political discourse. Urban imageries are neither coherent nor are they articulated in one and the same way by the people. City dwellers of the same social or cultural background may share an image of the city, but since urban societies are composed of many different milieus, city images can be as multifaceted as urban societies. The parallel persistence of nicknames for the same city hints at multiple milieus and their relative autonomy in urban imageries. In addition, idiosyncrasies play an important role. Each and every citizen may cultivate a different urban imagery and nurse other city images. Yet, again and again, stable city images did and do emerge - despite all the "mixture" and fragmentation of urban milieus along all possible lines. Does this process build on political articulation, extending it into another realm? Or is the 
formation of city images a different kind of process informed by the intrinsic, aesthetic qualities of pictures and images?

Assuming the latter leads to our second problem: Aesthetic politics - or political aesthetics - will have to take the sensory dimension of the visual and, by extension, the imagined city into account (Rancière 2000). But the aesthetic dimension is not articulated by the same discursive means as a simple question of service delivery, say, the provision of water and electricity in a spontaneous settlement. Hence the second challenge: If the actors do not make use of language to articulate their views, they may make use of other media, in particular visual media. Not using language does neither mean that the actors do not articulate their views nor does it imply that visual media are apolitical. On the contrary: because they may escape direct efforts to control political discourse, visual media such as photos, paintings, and, of course, caricatures - but also poetry and literature evoking images - may be more powerful than political articulation by other means. Because pictures show their subjects in ways that leave more space for interpretation (Boehm 2007) they are more difficult to control than words - and images are still more elusive than pictures. Very much the same holds true for the performing arts and also for the performative aspects of everyday life. They easily escape discursive constraints.

A short example may illustrate our point. People move in specific ways through the city. Their ways of moving depend to some extent on their profession, on their means, and not least on their social identity. An unskilled labourer who uses public transport in crammed vehicles, sometimes waiting at minibus stops for hours, will develop a different knowledge of the city than, say, a government employee who drives from home to office on his own motorcycle or car. Although they may live in the same town, they experience another city. They will develop another urban imagery, derived from different pictures and ways of seeing that reflect the visual environment's relevance to them as social actors. Such ways of moving 
largely become habitual and gradually constitute the background of the actors' urban imagery. ${ }^{8}$ Phenomenological studies of such sedimented experience are only a starting point as they often do not address the more profound challenge: How do the people articulate the imagery that they have acquired over time? How are their articulations perceived and recognised by other actors? And finally, when and how do they share their imageries or parts of them?

These questions go to the core of our argument. In order to understand the formation of city images, three consecutive moves are necessary: First, one needs to examine the various urban practices that different milieus of urban society engage in. Second, one needs to study how individual as well as collective actors articulate their respective urban imageries. Third, one has to look at how urban actors relate to the articulations of others. Of course, such an approach can only yield deeper insights if it is conceived as a circular methodology that leads back to the first set of questions. It is also method and theory thought as one.

The articles published in this special issue can be read as contributions to this theme: They follow the actors through their cities, they look at how pictures move through the cities, they explore when and where pictures turn into images, they trace how urban dwellers share pictures and images and how that eventually feeds into images of the city. Not least, the authors also examine how city images are perceived by outsiders. Artists are a special group of urbanites. They are perhaps best thought of as experts of their own cities. They know them because of their professional interest and develop city images that are of a different kind. They articulate such images not only in everyday talk but in media that they find more suitable to express their own experience of the urban in all its complexity. So, their city images are often broader and include aspects that others may not have noticed - but by the same token, they may also be more personal, more idiosyncratic. 


\section{The contributions to this issue}

This collection of articles is a result of the workshop Re-Imagining African Cities: The Arts and Urban Politics hosted by the Visual Culture Research Group at the Institute for Social Anthropology, University of Basel on 11-12 March 2016. ${ }^{9}$ The workshop built on the cooperation between the Chair of Social Anthropology at the University of Basel, the Collaborative Research Group "Visual and Expressive Cultures" of the Africa Europe Group of Interdisciplinary Studies (AEGIS), the Institute for Urban and Landscape Studies (later renamed Critical Urbanisms), and the Centre for African Studies at the University of Basel. Both, the workshop and this issue, are a result of long-standing research relationships and cooperation between members of the Institute and colleagues in American, African, European and other universities specialising in visual and performative culture in African cities.

Based on research in Kinshasa, Paris, Cape Town, Lagos, Bamenda, Korhogo, Freetown, Johannesburg and Kampala, the articles reflect the diversity and relevance of African cities in contemporary art practice. The range of artistic media involved in these practices - the articles include video works, performance, music and sound, photography, literature, paintings, drawings, sculptures, street art and installations - underscores this variety.

Even though the articles reflect city-specific particularities and differences, there are also commonalities and similarities in how these cities relate to broader societal contexts, urban imaginations and aesthetic practices. The focus of this special issue on visual and performing arts provides the vehicle and the critical means of observing, articulating and representing these entanglements of the cities as social and cultural spaces, their images and the artistic imagination. It also uncovers mobilities and medialities that connect cities and their art practitioners within global networks far beyond the African city. 
Many contributions to this special issue observe that cities always have a “double" (e.g. Förster) or a spatio-temporal counter-image as reflected in mikilisme (e.g. Malaquais). They are anything but a firm, defined and comprehensible entity, and tend to be characterised as "elusive" as in the case of Johannesburg (Nuttall and Mbembe 2008). Still, their inhabitants do create stable images of their cities and the urban life that they breed. As Till Förster suggests in his contribution to this special issue, cities have a "double;" they exist as an assemblage of material things and people on the one hand, and as objects or images in the minds of those who experience the city in their daily lives on the other. Theorising the city as an "intentional object" $" 10$, he argues that images of the city are a product of the human encounter with its "realities." Humans "need to imagine," as he states. This imaginary practice is not entirely autonomous and instead intermingles with dominant discursive formations about, and fixed representations of, cities that produce collective city images located somewhere between what he calls "lightness" and the "urban uncanny," idealised and dystopic images of African cities respectively. Difference and contrast indeed is a constitutive trope in the images of cities - the megacity vs. the rural village, the "chaotic" African city versus the "orderly" European or American city. Urban experience and the imageries it creates are always relational.

Cities also tend to occupy "third space," as Dominique Malaquais argues in her contribution about $G O U$, a failed transcontinental art project between Kinshasa and Paris: "Paris may be Paris, but in places - the Château Rouge and Gare du Nord neighbourhoods, in particular - it is first and foremost Kinshasa." African and European cities, the colonial metropolis and the postcolonial megacity thus “emerge as extensions of one another, one possible only because of the existence of the other." This can result in highly fruitful transnational co-operations but also in a personal and professional experience of structural violence. This urban translocality, being in "this place and that place at one and the same time", even emerges without actual bodily translocation, as Carol Magee demonstrates in her discussion 
of Nigerian artists and photographers Emeka Ogboh, Uche Okpa-Iroha and Abraham Oghobase. Even if photographs are produced in particular places, the very moment of production takes their nature as reproductive and transportable media into consideration: the imagined audiences of the artists are located not only within the city they photograph, but also and perhaps foremost beyond it, in other towns and continents. This conversation between cities can materialise even more radically when artists extend their media beyond the visual and succeed in appresenting a place with music rather than representing it with an image. By appresenting the city as a place in a wider context, the artists evoke possible perceptions and conceptions - while representing a city would determine it to only one image.

These mobilities and medialities are a fundamental part of how we make sense of the world and our cities, and they inform our awareness of the politics of urban space. In her contribution, Heike Becker shows how the Marikana massacre in a mine not far from Johannesburg in 2012 is appropriated for urban justice and de-colonial activism in Cape Town 1,500 km away. Commemoration performances and interventions in the streets and public places as well as in elitist university buildings are aesthetic means by which artists engage the political entanglement of gentrification, urban poverty in South Africa, and a neo-liberal education system that not only inherited hegemonies established during apartheid, but also is actively imbricated in the plight of the contemporary working class. The urban space here becomes the platform where artists tackle national issues, turning the city of Cape Town into their stage, platform and medium of expression for political concerns that both transgress but also shape this very city.

Similarly, the transatlantic slave trade has fundamentally informed Lagos as a city entangled in a transnational and local network of colonial and political violence. In her contribution about word-photography configurations in Every Day Is for the Thief (2007/2014), Gabriele Rippl shows how the writer Teju Cole unveils histories and narratives of Lagos that have been relegated to collective amnesia in 
the city's own memory. Discussing Cole's own approach in his book to reveal narrative and representational gaps in city representations by combining text and photography, she underscores his observation that " $[\mathrm{t}] \mathrm{o}$ look is to see only a fraction of what one is looking at." The power of representation is questioned and subverted in a deliberate combination of visual and narrative genres that traditionally have claimed truth: documentary photography and travelogues.

Migrations and trajectories as experienced by Cole and his protagonist have a striking presence in almost all articles. It appears that only this oscillating movement between entering, traversing, strolling, exiting and re-entering the city enables images and imaginations of the city. At the same time, it also generates new forms of cultural practice and artistic expression. Amanda Maples presents in her contribution a case in point with the Ordehlay masquerades of Freetown. She argues that "the specificity of Freetown as urban locality has allowed for the invention of unique masquerades." From its very beginning, Freetown was a "diaspora," formed from a "repatriated" population that had migrated with the slave trade to the USA. This migration history fundamentally constitutes the urban identity of Freetownians. In addition, as an art form that emerges from migration, the masquerades are themselves highly mobile in their exploration of Freetown's urban space and in the way they engage urban politics and their patrons. Tracing the history of Ordehlay associations and masquerades to their origins, their ban as a means of urban political control, and their re-introduction as a significant cultural medium of urban and political representation, Maples shows that Ordehlay in Freetown is both specific to Freetown and globally connected, an associational cultural expression and a subversive genre of political mobilisation.

This applied in similar ways to the photographic and social practices of the Chinese Camera Club in apartheid South Africa. As Malcolm Corrigall shows in his article, the club members fused the performative practice of exploring urban space with the indexical medium of photography in their photographic outings, thus 
challenging the powerful means of territorial control and representational violence typical to apartheid. Capturing particular sites of Johannesburg in their photography and thereby suggesting their presence and participation in South African citizenship and success, the photographers transformed their marginalised position into one from where they could speak - in visual and counter-representational ways. Representing spaces in photography also went along with occupying representational spaces of the city for key events like the Chinese Photography Salon in occasion of the 1956 Johannesburg Festival. Just because these practices were not overtly oppositional, they opened up the imaginary of being both a rightful constituency in a racist city and an internationally organised Chinese expatriate society.

Even if African cities often lack governmental support, infrastructure and funding for contemporary art, their social and physical spaces can be activated for artistic initiatives as discussed by Fiona Siegenthaler in her contribution. Questioning tropes of urban artistic practices as something subversive and anti-establishment, she suggests to think of co-optation as a technique of artistic imagination in African cities. Contemporary artists and curators in Kampala rely and build on established networks and social spaces for their initiatives, thereby co-opting different stakeholders as the situations afford, amongst them fellow artists, NGOs and the local elite. They find innovative means to fundraise projects, and to appeal to yet untapped patronage arrangements. Apart from constituting an established centre of "cultural production," the city thereby unfolds also as an economically diversified space where certain social spaces can be accessed by activating particular physical places in the city as points of encounter and visibility.

\section{The appeal of African cities}

So, what makes African cities so appealing, not only for the contributors to this issue, but for an ever-growing community of researchers attracted to the aesthetics, politics, logics and rhythms of African cities? The answer maybe lies in the 
fact that in spite of anonymity and independence, solitude in the mass, physical compression and mental distanciation, temporal condensation and networked expansion - all characteristics described by Georg Simmel ([1903] 1989) for the modern European city - the city is and remains an "intentional object". On the one side, it is a sedimentation of lived experiences of social actors and on the other, it is a manifestation of how these actors weigh and judge their experience when they are confronting urban life. In other, seemingly paradoxical words, the city is an "imagined reality" - very much as a nation is an imagined community of immediate political relevance (Anderson 2004). The city therefore also has a communal or collective force, even when one of its distinguishing effects is individuation.

While this relationship between the material and the imagined city seems natural and mostly goes unnoticed in the everyday practice of urbanites, artists tend to bring it into light with their diverse means of aesthetic expression. They reflect the city, its materiality, its characteristic image and its societal imagination in different ways. Thereby, they emphasize both the poetics and the politics of the material city and the urban imagination. They disclose social inequity reflected in territorial politics, they intervene in public space with socio-political motivations, they offer youth or marginalised parts of the population creative means for stating their claim for the right to the city, and sometimes they simply dwell on its beauty. By the same token, they also create connections between disparate urban milieus, transform local identities into transnational networks, and their art activities contribute to shaping the international image of a city. Cities are also places of professional networks and thus serve as a fertile ground for cooperative art activities. Cities are the places where identities of "art scenes," creative groups and an intellectual creative class are articulated - sometimes in elitist and exclusive ways and at times at the bottom of social hierarchies. 


\section{References}

Amin, A., and N. Thrift. 2002. Cities: Re-Imagining the Urban. Cambridge: Polity Press.

Anderson, B. 2004. Imagined Communities: Reflections on the Origin and Spread of Nationalism. London: Verso.

Bayart, J.-F. 1989. L'Etat en Afrique. Paris: Fayard.

Boehm, G. 2007. Wie Bilder Sinn erzeugen: Die Macht des Zeigens. Berlin: Berlin University Press.

De Boeck, F., and M.-F. Plissart. 2014. Kinshasa: Tales of the Invisible City. Leuven: Leuven University Press.

Förster, T. 2017. "Envisioning the City in Africa: Anthropology, Creativity and Urban Culture." In The Palgrave Handbook of Creativity and Culture Research, edited by V. Glaveanu, 449-471. London: Palgrave.

Freire, M., S. Lall, and D. Leipziger. 2015. “Africa's Urbanization: Challenges and Opportunities." In The Oxford Handbook of Africa and Economics, vol. 1: Context and Concepts, edited by C. Monga, and J. Yifu Lin. New York: Oxford University Press.

Hall, S. 1997. “The Work of Representation.” In Representations: Cultural Representations and Signifying Practices, edited by S. Hall, 13-74. London: Sage.

Konings, P. 2006. “'Bendskin’ Drivers in Douala's New Bell Neighbourhood: Masters of the Road and the City." In Crisis and Creativity: Exploring the Wealth of the African Neighourhood, edited by P. Konings and D. Foeken, 46-65. Leiden: Brill.

Malaquais, D. 2006. "Une nouvelle liberté? Art et politique urbaine à Douala (Cameroun)." Afrique et Histoire 5 (1): 111-134.

Miles, M. 2007. Cities and Cultures. London: Routledge.

Mitchell, W.J.T. 1994. Picture Theory. Chicago: University of Chicago Press. 
Myers, G. 2011. African Cities: Alternative Visions of Urban Theory and Practice. London: Zed.

Nuttall, S., and A. Mbembe, eds. 2008. Johannesburg. The Elusive Metropolis. Johannesburg: Wits University Press; Duke University Press.

Okeowo, A. 2013. "A Safer Waterfront in Lagos, If You Can Afford It." The New Yorker, August 20, 2013, http://www.newyorker.com/business/currency/asafer-waterfront-in-lagos-if-you-can-afford-it. Accessed 25 August 2017.

Rancière, J. 2000. Le Partage du Sensible: Esthétique et Politique. Paris: La Fabrique.

Rizzo, M. 2017. Taken for a Ride: Grounding Neoliberalism, Precarious Labour, and Public Transport in an African Metropolis. Oxford: Oxford University Press.

Robinson, J. 2006. Ordinary Cities: Between Modernity and Development. New York: Routledge.

Simmel, G. (1903) 1989. "Die Grossstädte und das Geistesleben”. Gesamtausgabe vol. 7, edited by O. Rammstedt, 116-131. Frankfurt a. M.: Suhrkamp.

Simone, A. 2004a. For the City Yet to Come: Changing African Life in Four Cities. Durham, NC: Duke University Press.

Simone, A. 2004b. "People as Infrastructure: Intersecting Fragments in Johannesburg." Public Culture 16 (3): 407-429.

Simone, A. 2010. City Life from Jakarta to Dakar. New York: Routledge.

Thrift, N. 2008. Non-Representational Theory. London: Routledge.

UN Habitat. 2016. Urbanization and Development: Emerging Futures. World Cities Report 2016. New York: United Nations. 


\section{Endnotes}

1 Outstanding theoretical contributions of that kind are Amin and Thrift (2002) and Miles (2007).

2 Highly seminal were the analyses of Simone (2004a, 2004b, 2010) who sees "urban life as a context for intersection" $(2010,115)$. For Simone, this characteristic is linked to the "blackness" of cities in the Global South (2010 passim) - a term that, Simone claims, points at the "multiplex" of such cities (2004a, 241-243). We believe that such broad generalisations are but a first step toward more sophisticated theories of the urban that need to be grounded in thorough empirical research. See also de Boeck and Plissart (2014) and the general discussion by Myers $(2011,12-14)$.

3 We thus make use of Mitchell's (1994) heuristic conceptualisation of (material) picture and (mental) image. However, we are aware that such a heuristic conceptualisation is problematic as it largely ignores the continuity between the two concepts.

$4 \quad$ Critically Hall (1997), for a non-representational theory of the urban see Thrift (2008).

5 http://www.barrypopik.com/index.php/new york city/entry/africas big apple lagos nickname/, Accessed 25 August 2017.

$6 \quad$ South Africa is certainly a notable exception.

7 See, for instance, the debate about Douala's Nouvelle Liberté (Malaquais 2006).

8 See Konings (2006) for the motorcycle drivers' perspective in Douala, Cameroon; and Rizzo (2017) for a general analysis of matatu transport in Dar-esSalaam, Tanzania. 
9 This workshop and especially the participation of contributors from Africa, the USA and Europe was generously supported by Swiss - African Research Cooperation (SARECO) and Freiwillige Akademische Gesellschaft (FAG).

$10 \quad$ See also Förster (2017). 